\title{
Sorghum market integration study in Ghana
}

\author{
W. QUAYE \& G. Y. AMELEKE \\ (W. Q.: CSIR-Food Research Institute, P. O. Box M.20, Accra, Ghana; G. Y. A.: CSIR-Animal Research \\ Institute, P. O. Box AH20, Achimota, Accra, Ghana)
}

\begin{abstract}
The study sought to examine the variability and trends in sorghum supply and prices, factors affecting volumes of sorghum traded, and whether the sorghum market was integrated. To achieve the set objectives, primary and secondary data were used. A random sample size of 160 respondents, including 20 per cent sorghum grain itinerant traders, 43 per cent wholesalers, 17 per cent retailers, and 20 per cent consumers were interviewed in selected markets in Northern and Brong Ahafo regions in Ghana. These markets were selected by production and utilization levels, and accessibility as well as potential for sorghum market expansion. Monthly observations over the period 1990-1999 on sorghum prices at the wholesale level for the selected markets were used for the market integration analysis. The study adopted various analytical approaches, including the basic Ravallion model with some modifications and the Error Correction model, to test for sorghum market integration. The study showed that the actual marketing of sorghum was organized by many individual private traders with no barrier to market entry. Factors affecting volumes of sorghum traded are variable and location-specific. These factors include transportation difficulties, limited supply, inadequate capital, lack of finance, number of sellers and buyers, risk of price changes, and quality deterioration. The study established lack of short-run integration in 75 per cent of the sorghum market pairs studied. The price adjustment mechanism between local market and reference market was relatively slow, but markets were integrated in the long run. This could be attributed to lack of an adequate market information system at the rural markets, and possibly transportation difficulties. It was recommended that the efficiency of the sorghum marketing system needed to be improved by strengthening the market information system.
\end{abstract}

Original scientific paper. Received 18 Mar 05; revised 20 May 07.

\section{RÉSUMÉ}

Quaye, W. \& Ameleke, G. Y.: Etude d'intégration du marché de sorgho au Ghana. L'étude visait à étudier la variabilité et les tendances de la provision et les prix de sorgho, les facteurs influant sur les volumes de sorgho commercé et si le marché de sorgho était intégré. Pour atteindre les objectifs fixés, les données primaires et secondaires étaient utilisées. Un échantillon pris au hasard de 160 personnes interrogées comprenant vingt pour cent $(20 \%)$ marchands itinérants du grain de sorgho, quarante-trois (43\%) grossistes, dix-sept pour cent $(17 \%)$ détaillants et vingt pour cent $(20 \%)$ consommateurs étaient interrogés aux marchés sélectionnés dans les régions de Nord et de Brong Ahafo au Ghana. Ces marchés étaient sélectionnés d'après les niveaux de production, d'utilisation, d'accessibilité et de possibilités pour l'expansion du marché de sorgho. Les observations mensuelles sur la période de 1990-1999 de prix de sorgho au niveau de grossiste pour les marchés sélectionnés étaient utilisés pour l'analyse d'intégration du marché. L'étude a adopté des diverses approches analytiques y compris le modèle Ravallion fondamental avec quelques modifications et le modèle Correction d'Erreur pour faire une analyse pour l'intégration du marché de sorgho. L'étude révélait que la commercialisation réelle de sorgho était organisée par un grand nombre de marchands privés individuels sans barrière au lancement sur le marché. Les facteurs influant sur les volumes de sorgho commercés sont variés et spécifiques à chaque endroit. Ces facteurs comprennent les difficultés de transport, la provision limitée, l'insuffisance de capitaux, le manque de fonds, le nombre de vendeurs/ acheteurs, le risque de révision des prix et la détérioration de la qualité. L'étude a montré le manque d'intégration à court terme en 75 pour cent de paires des marchés de sorgho étudiés. Le mécanisme d'ajustment des prix entre le marché local et le marché de référence était relativement lent mais les marchés étaient intégrés à long terme. Ceci pourrait être attribué au manque de système d'information mercatique adéquat aux marchés ruraux et peut-être aux difficultés de transport. Il est recommandé que l'efficacité du système de marketing de sorgho exige d'être améliorée par la consolidation du système d'information mercatique.

Ghana Jnl agric. Sci. 41, 35-47 


\section{Introduction}

Sorghum [Sorghum bicolor (L) Moench] has been identified as one of the food security crops and has been receiving research attention recently. It is one of the most widely cultivated cereals and an important staple in the semi-arid tropics. In Ghana, the area cultivated under sorghum is only exceeded by maize in the Northern Region and by millet in the Upper East and Upper West regions. Sorghum is also grown to a limited extent in the Brong Ahafo, Volta and Greater Accra regions. The total production of the crop has, however, not increased over the years as a result of low yields. The low yields are due to the cultivation of indigenous varieties with inherent low yield potential, lack of fertilizer, and the low-planting densities characteristic of the traditional mixed cropping systems. In view of this, a project under Crops Research Institute for the Semi-Arid Tropics (ICRISAT) and funded by the International Fund for Agricultural Development (IFAD) was started in 1999 with a general objective of increasing sorghum productivity in five West African countries, including Ghana. Under the project, farmers were assisted to get access to good quality seeds. Other operators in the sorghum industry received technical assistance to improve their practices, diversify sorghum utilization, and expand the market base for sorghum. The project in Ghana was led by the Food Research Institute (FRI) with Savanna Agricultural Research Institute (SARI), Animal Research Institute (ARI), Ministry of Food and Agriculture (MOFA), and ACTIONAID (an NGO) as collaborators.

The quest for market expansion necessitated an in-depth study on the existing marketing system of sorghum as part of the activities under the project in Ghana. Markets are the means to allocate resources to ensure high value production and consumer satisfaction, and also to stimulate growth by promoting technological innovations as well as providing incentives to develop new sources of supply (Smith, Khusk \& Stockbridge, 1999). Markets, through their influence on incomes, prices and commodity flows, play a crucial role in determining national levels of, and consumer access to, food. It was, therefore, thought that marketing research inputs were needed to maximize the probability of commercial uptake of any technical research output and make research results more efficient and effective.

This study broadly focused on market integration as a measure of market performance. The performance of marketing systems is considered important because efficiency and competition depend on accurate, timely and available price information. The usual definition of market integration infers that integrated markets are those in which prices are determined interdependently. This has generally been assumed to mean that price changes in one market will be fully passed on to other markets (Takayama \& Judge, 1971; Lutz \& van Tilburg, 1997). Integration is best reflected by flow-based indicators of tradability (Barrett \& Li, 2002; Barrett, 2001). Markets that are not integrated may convey inaccurate price signals that might lead to inefficient product movements. Markets may be linked through the competitive profit-seeking activities of arbitragers (Jayne, Takavarasha \& Johan van Zyl, 1994; Goodwin \& Schroeder, 1991), and an integrated market is one in which arbitrage works well by ensuring that a unique equilibrium is reached when local prices in alternative markets differ by no more than transaction cost.

To understand why (or why not) markets are integrated, the need is to understand the factors affecting market integration (Goletti \& Babu, 1994). These factors include marketing infrastructure, government policy, dissimilarities in production, and supply shocks. Knowledge about the extent to which markets are integrated is important for several reasons (Maheshwari, 1993). First, identification of closely integrated markets and knowledge about the extent of price transmission across different locations within a country may help a government improve the design of its market policies. Knowledge of market integration allows monitoring of price movements. Integration models can also be used to forecast prices all over 
a country, because knowing the relationship among prices in the neighbouring markets facilitates forecasting analysis. Market integration is key to the sustained success of extension of new production technologies, which might otherwise flood stagnant local markets with unsaleable surpluses. Finally, by identifying structural factors responsible for market integration, investment policy in marketing infrastructure can be improved. This allows policy makers to understand which kind of marketing infrastructure is more relevant to developing agricultural markets in a country.

Specifically, the study sought to examine the variability and trends in sorghum supply and prices, factors affecting volumes of sorghum traded, and to find out whether the sorghum market is integrated.

\section{Materials and methods}

Data collection and analysis

To achieve the above objectives, primary and secondary data were used. An informal survey, which preceded a formal survey, was used to generate qualitative information on the issues raised in the specific objectives. Qualitative information gathered served as a guideline for designing structured questionnaire for formal survey. The structured questionnaire was pretested and the necessary changes effected. The survey covered markets including Zebilla and Bawku markets in the Upper East Region, and Tamale and Techiman in the Northern and Brong Ahafo regions, respectively. These markets were selected based on sorghum production and utilization levels, accessibility, and potential for market expansion. To solve the problem of representativeness, in temporal and spatial limitation on coverage, stratified sampling procedure was used. A sample size of 160 respondents consisting of 20 per cent sorghum grain itinerant traders, 43 per cent wholesalers, 17 per cent retailers, and 20 per cent consumers were covered. Other participants involved in sorghum marketing like commission agents, district assembly staff in charge of market infrastructure management, PPMED-MOFA, and transporters were also interviewed using a checklist. The interviews were on market days at the market centres. Monthly observations over the period 1990-1999 on sorghum prices at the wholesale level for the selected markets were used for the market integration analysis. Responses from primary data collection were coded. Statistical Package for Social Sciences (SPSS) and Microsoft Excel were used to process the data for descriptive analysis. Econometric Views software package was used for market integration analysis.

\section{Market integration}

In this study, the Ravallion approach was complemented with the cointegration approach to analyse market integration. The Ravallion approach was used to test the hypothesis of short-run integration, while the cointegration approach was used to test long-run market integration. After the confirmation of long-run integration (cointegration), the short-run was again tested for using the Error Correction model.

\section{The Ravallion approach}

Spatial market integration emanates essentially from the Law of One Price (Takayama \& Judge, 1971). The Law of One Price means that the prices of a single commodity in two geographical areas will differ only by the transport cost between them. Thus, it is expected that changes in the price of a commodity in one market will be related to changes in the price of the same commodity in another market to which the first one is linked.

Ravallion (1986) postulated a radial market arrangement in which a central or reference market is linked to other local markets. The price in the reference market is dependent on the prices in the other local markets, and a vector of seasonal and policy variables (Equation 1).

$$
P_{1}=f_{1}\left(P_{2}, \ldots P n, X_{1}\right)
$$

Where $\mathrm{P}$ is price of the commodity, $\mathrm{X}$ is the vector of policy variables, 1 denotes the reference 
market, and 2 ... n denote the n-1 local markets.

The local market price $\left(\mathrm{P}_{\mathrm{i}}\right)$ is also dependent on the reference market price $\left(\mathrm{P}_{1}\right)$, and a vector of seasonal and policy variables $\left(\mathrm{X}_{\mathrm{i}}\right)$ in the local market (Equation 2). It is assumed that the other local market prices contribute little to the determination of $\mathrm{P}_{\mathrm{i}}$.

$$
P_{i}=f_{i}\left(P_{1}, X_{i}\right)
$$

To capture the dynamic nature of price formation in the markets, Ravallion (1986) proposed Equations 3 and 4 as the counterparts of 1 and 2, respectively. The dynamic effects could arise from several conditions in the underlying behavioural relations, including expectation formations and adjustment costs (Hendry, Pagan \& Sargan, 1984).

$$
\begin{gathered}
P_{1 t}=O_{j=1} a_{1 j} P_{1 t-j}+O_{k=2} O_{j=0} b_{1 k j} P_{k t-j}+c_{1} X_{1 t}+e_{1 t} \\
(j=0,1)
\end{gathered}
$$

In Equation 3, the current price in the reference market is dependent on the previous reference market prices, and current and previous local market prices.

Where $\mathrm{k}$ denotes local market and $\mathrm{j}$ denotes number of lags.

Equation 4 also signifies that the current local market price is dependent on previous local market prices, and current and previous reference market prices.

$$
\begin{gathered}
\mathrm{P}_{\mathrm{it}}=\mathrm{O}_{\mathrm{j}=1} \mathrm{a}_{\mathrm{ij}} \mathrm{P}_{\mathrm{it}-\mathrm{j}}+\mathrm{O}_{\mathrm{j}=0} \mathrm{~b}_{\mathrm{ij}} \mathrm{P}_{1 \mathrm{t}-\mathrm{j}}+\mathrm{c}_{\mathrm{i}} \mathrm{X}_{\mathrm{it}}+\mathrm{e}_{\mathrm{it}} \\
(\mathrm{i}=2, \ldots \mathrm{n}),(\mathrm{j}=0,1)
\end{gathered}
$$

Having noted that Equation 3 is unidentified in a lot of cases, Ravallion (1986) concentrated on Equation 4.

Several hypotheses can be tested including segmentation, short-run and long-run market integration. This was achieved by testing the parameter restrictions on Equation 4 as follows:

\section{Hypothesis statement}

1. Complete market segmentation

If $b_{i j}=0$ for all values of $\mathrm{j}$ in Equation 4 , then prices in $i^{\text {th }}$ market are segmented from the reference market. In other words, prices in the reference market do not influence prices in the local market.

\section{Short-run market integration}

On the contrary, if $b_{i 0}=1$, then prices are immediately transmitted. This implies that $\mathrm{a}_{\mathrm{ij}}=\mathrm{b}_{\mathrm{ij}}$ $=0$, $($ when $\mathrm{j}=0)$, and thus only the current reference market price affects $\mathrm{P}_{i}$.

Thus, $b$ is a measure of the degree to which changes in prices in the reference market are transmitted.

\section{Long-run market integration}

For long-run equilibrium conditions, market prices are constant over time and undisturbed by any local stochastic effects. Also, if markets are integrated in the long run, the sum of the price coefficients equals 1 , i.e.

$$
O_{\mathrm{ijj}}+\mathrm{Ób}_{\mathrm{ij}}=1
$$

The two-stage least squares method of regression was performed on Equation 4, using price series in their natural logarithms. From literature, with estimation using price differences in their natural logarithms, proportional marketing margins are implicitly assumed; whereas using original series gives absolute marketing margins (Dercon, 1995). The two-stage least squares regression method was used as a check against any bias that could exist from failure to correct for the simultaneous determination of prices. The short-run hypothesis was then tested.

Zebilla, Bolgatanga, and Bawku markets in the Upper East Region, which were considered to be sorghum-producing areas, were selected as the local markets in this study. The region is linked to the rest of the country by a single trunk road 
through Tamale and further to consuming areas in the southern part of Ghana. Other local markets used included Bimbilla and Gushiegu in the Northern Region. Some reference markets considered in the study included Accra, Techiman, and Tamale. These markets were selected for the market integration studies based on the observed distribution channels for sorghum.

\section{The cointegration approach}

The Ravallion model and its modifications have been criticized because the stationarity status of the variables are not tested, and results based on non-stationary variables could be spurious (Charemza \& Deadman, 1992). A linear combination of non-stationary variables can be stationary or cointegrated. Cointegration of variables implies co-movement in the long run and, therefore, provides an alternative means of assessing market integration. When variables are cointegrated, then an Error Correction model also exits (Engle \& Granger, 1987). This Error Correction model represents the short-run dynamics of $\delta_{\text {market integration. }}$

\section{Unit root test}

The Augmented Dickey-Fuller (ADF) unit root test was used to determine the stationarity of the series (in natural logarithms) and the order of integration. The order of integration depicts the number of times a series has to be differenced to be stationary (Charemza \& Deadman, 1992) for cointegration test to be applied. A variable is said to be integrated of order d, I(d), if it attains stationarity status after differencing d times. The Dickey-Fuller test involves estimating Equation 5 below and testing the significance of ä using critical values from Fuller or Mackinnon tables.

$$
\Delta P_{t}=C+\alpha . t+\delta \cdot P_{t-1}+\ell_{t}
$$

Where $\Delta P_{t}$ is the first difference of a price series

$$
P_{t,} \text { defined as } p_{t}-p_{t-1} \text {, }
$$

$t$ represents time trend

$C$ is a constant term $e$ is stochastic disturbance term

Because there could be autocorrelation in the series, the ADF test becomes a more efficient test here. The ADF is specified as:

$$
i=1
$$

$\mathrm{n}$ is the number of lags needed to eliminate serial correlation in the system. The following hypotheses were tested on Equation 6:

$$
\begin{aligned}
& H_{1}: \delta \angle 0 \\
& H_{0}: \delta=0
\end{aligned}
$$

The rejection of the null hypothesis in favour of the alternative hypothesis implies that $\mathrm{P}_{\mathrm{t}}$ is integrated of order zero or $\mathrm{P}_{t} \sim \mathrm{I}(0)$. If the $\mathrm{H}_{0}$ is not rejected, it means that $\mathrm{P}_{\mathrm{t}}$ is non-stationary.

\section{Cointegration and error correction model (ECM)}

Using the two-step residual-based test (Engle \& Granger, 1987; Alexander \& Wyeth, 1994; Lutz et al., 1994; Goletti et al., 1994; Dercon, 1995), the long-run market integration between the market pairs under the study is determined. The estimation procedure involves regression using ordinary least square on Equation 7. The residuals from Equation 7 are retrieved and unit root tests performed on the retrieved residuals as in Equation 8. Integration of order zero implies stationarity of the residuals and, therefore, cointegration of the two price series.

$$
\begin{aligned}
& p_{t}^{i}=a+b P_{t}^{j}+\ell_{t} \\
& \Delta \ell_{t}=\alpha+\beta \ell_{t-1}+\delta_{t} t+\sum_{j=2}^{n} \lambda_{j} \Delta \ell_{t-j}
\end{aligned}
$$

The ECM model (Equation 9) was used for short-run market integration (Engle \& Granger, 1987; Hendry et al., 1984) test.

$$
\Delta \mathrm{P}_{\mathrm{it}}=\alpha_{\mathrm{i}}+\beta_{\mathrm{i}} \Delta \mathrm{P}_{1 \mathrm{t}}+\gamma \mathrm{i} \Delta \mathrm{P}_{\mathrm{it}-1}+\mathrm{ie} \mathrm{e}_{\mathrm{t}-1}
$$

\section{Results}

Key actors involved in sorghum marketing The actual marketing of sorghum was organized 
by many individual private traders, who took the responsibility of ensuring adequate and regular supply of sorghum to cities and deficit rural areas. Coordination of their activities was rather informal (Morgan \& Hunt, 1994); each trader made the necessary arrangements for an efficient execution of his or her business. No cooperative marketing approach was practiced, and there had not been any governmental control over volumes traded and pricing since its trade liberalization policy was implemented under the Economic Recovery Programme (ERP) in 1983. The government of Ghana was, however, committed to providing comprehensive and timely market information services through MOFA activities (MOFA, 1990). The government was also pursuing construction of market infrastructure even at the rural level to enhance commodity movement to the consumption centres. The main participants in the sorghum marketing system included assemblers, commission agents, wholesalers, and retailers. Others who performed market-facilitating functions included creditors or money lenders, stall owners, transporters, and MOFA.

Assemblers (itinerant wholesalers). Assemblers provided the most permanently available outlet for marketable surplus at the rural level and sometimes gave production credit to farmers. The assemblers, who were either residents or outsiders, sourced produce from farmers' fields or houses and local markets. Those who did not have adequate knowledge of local supply and demand conditions used the services of buying agents. Some credible agents were also given cash advances to facilitate purchasing.

Commission agents. Commission agents did not take title to the goods and, therefore, did not bear any marketing risks, but made transactions for the traders for a fee (1000-2000 cedis/bag). The two levels identified were the village and marketlevel commission agents. The village-level commission agents sourced sorghum from surrounding villages or producing areas close to their villages, using the visiting traders' capital. The market-level commission agents operated in urban markets for visiting traders. They sometimes made extra money when sorghum was bought or sold above the price agreed on with owners.

Wholesalers. Wholesalers sold in bulk to other visiting wholesalers or to retailers. They did not rush in selling because large stocks were held, using their own storage facilities, to ensure availability throughout the year and, most importantly, to get attractive prices. Treated grains were stored for a maximum of 1 year.

Retailers. Retailers were permanent traders whose activities were restricted to their local markets. They sold in small quantities to consumers in bowls (a bowl of sorghum was about $2 \mathrm{~kg}$ ). Sales per week per retailer were up to 20 bags (a bag of sorghum weighs between 95 and $110 \mathrm{~kg}$ ), depending on the location and demand conditions. Unsold grains were kept in rented stores at the end of each marketing activity.

Transporters. Transport is an important marketing facility linking production centres to consumption centres. It was observed in this study that traders made prior transportation arrangements with transporters for commodity movements between markets. The relationship between traders and transporters could be described as healthy; therefore, traders did not always accompany their goods. So packaging materials were marked for identification purposes. Head load, push trucks, donkey carts, bicycles and tractors were used to transport grains from the farm gate to the assembling point for onward transportation by trucks to urban markets. It was also observed that all the markets visited attracted traders from southern Ghana as well as within the regions.

\section{Seasonal variation in supplies and prices}

Seasonality in sorghum supply is reflected in pricing. Sorghum cultivation is unimodal with harvesting in October-December, depending on the rainfall pattern in any particular year. Stocks are held for stable supply throughout the year, especially at the market level. The survey showed that farm-level storage was minimal because of 
urgent cash needs by farmers. Thus, it became difficult for producers to offset the effect of seasonal variations. Supply on the market after the harvesting season was highly controlled by traders. Sorghum prices peaked in NovemberDecember while low prices were registered in January-February after the harvesting period. Fig. 1 illustrates a single seasonal price index (10 years' average for each month) curve, which was generated from average monthly prices over the period 1989-1999. It was observed that such seasonal patterns were well known to sellers and consumers. Consumers got around this problem by substituting among commodities, thereby lessening the effect of price fluctuations. As supported by Alderman (1990), this is possible because the Ghanaian food budget, as well as the diet, is divided among several commodities. Thus, the movement of one commodity price directly affects others because of shift in demand induced by substitution.

However, planning to take advantage of commodity substitution and storage to offset seasonal patterns (Sahn, 1989) becomes difficult when irregularities are in seasonal peaks as might occur with uncertainties. Generally, the day's price for sorghum was fixed by the first trader at the market, a price mostly equal to the closing price of the previous market in that area. Other traders quickly followed deviation from this price, depending largely on the supply and demand situation; so most markets had many traders selling at the same price.

The survey showed that to a lesser extent, trade associations influenced price determination. This was observed in Techiman market where sorghum traders commonly agreed on the going price by adding a margin on the buying price and transaction cost. It was realized that the individual farmer at the rural market generally sold quantities that were not enough to influence the level of prices ruling in any particular market. The individual farmer was a price taker. Farmers usually sold through a broker or a commission agent, especially at the urban markets.

The survey showed that few (5\%) sorghum producers sold their produce directly to the final consumer. In the rural markets, however, most producers depended on the complex chain - from the farm through various intermediaries before reaching the final consumer. Itinerant traders used the services of local agents to assemble produce

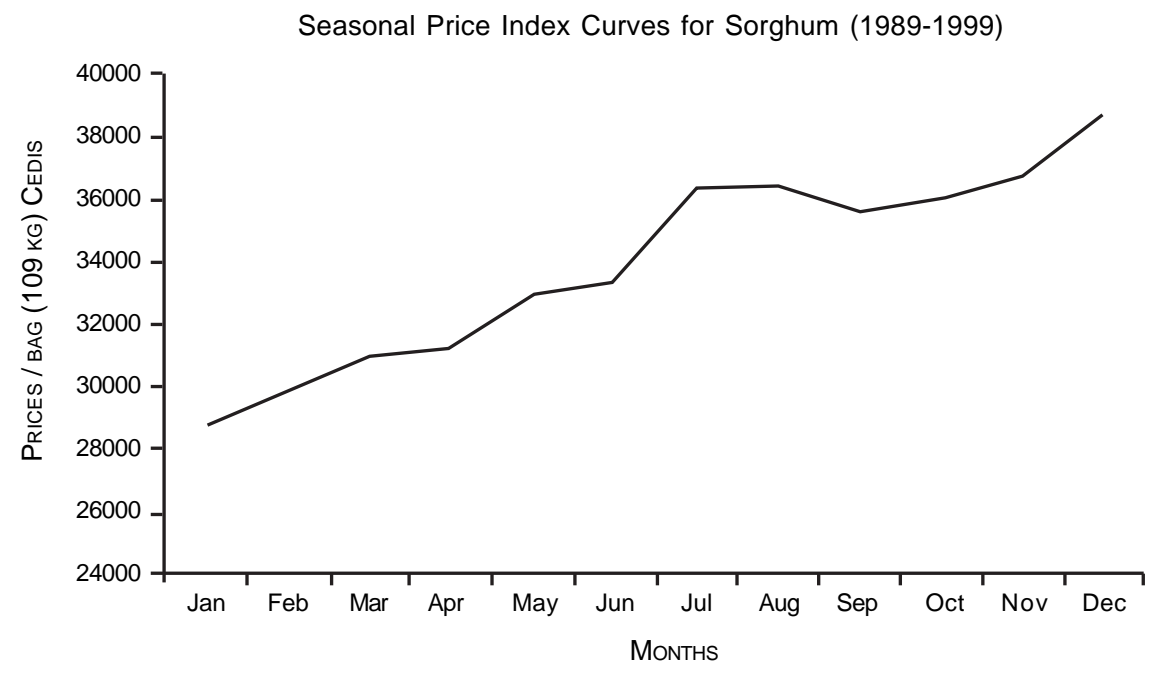

Fig. 1. Seasonal price index for sorghum. 
at the rural periodic markets, which were organized on a 6-day cycle. Marketing of sorghum was extensive and involved two or more wholesalers because of the high storability of the commodity. The first-level wholesaler (assembler) sold to the second-level wholesaler who usually linked different markets, especially sub-urban markets to urban wholesale markets in the south. Movements of these wholesalers were guided by price signals and supply availability information provided by MOFA, commission agents, or by visiting the markets themselves. It was also gathered from this study that appreciable amount of sorghum grain was imported from Burkina Faso, although the exact level of cross-border trade had not been determined.

Factors affecting volumes of sorghum traded

Factors affecting volumes of sorghum traded were variable and location-specific. These factors included transportation difficulties, limited supply, inadequate capital, lack of finance, number of sellers and buyers, risk of price changes, and quality deterioration (Table 1). At the Techiman market, the most pressing factors affecting volumes of sorghum grain traded were limited supply, lack of finance, inadequate capital, and number of sellers. The most important factors that seemed to affect volumes traded in the Tamale market were lack of finance, inadequate capital, limited supply, and risk of price changes. Limited supply, inadequate capital, lack of finance, and risk of quality deterioration were ranked as the first four important factors affecting volumes of grain traded at the Zebilla market. At the Bawku market, inadequate capital, limited supply, transportation difficulty, and lack of finance were ranked most important in a similar order.

\section{Market integration}

The Ravallion approach

Table 2 presents the estimation results using the Ravallion model on 19 out of the 20 market pairs under study. The statistical significance of the coefficients of the exogenous variables using the t-test indicated the existence or otherwise of integration between any given market pair (Table 3 ). There was significant improvement in the model when prices were lagged one period as in Timmer (1987) and Heyten (1986). Sometimes the regression coefficients were negative but significant; suggesting that high-lagged prices in reference markets could have the effect of lowering prices in the local markets. The trend

TABLE 1

Factors Affecting Volumes Traded

\begin{tabular}{|c|c|c|c|c|c|c|c|c|}
\hline \multirow[t]{2}{*}{ Factor } & \multicolumn{2}{|c|}{ Techiman } & \multicolumn{2}{|c|}{ Tamale } & \multicolumn{2}{|c|}{ Zebilla } & \multicolumn{2}{|c|}{ Bawku } \\
\hline & Score & Rank & Score & Rank & Score & Rank & Score & Rank \\
\hline Transportation difficulty & 6 & 8 & 69 & 6 & 8 & 7 & 118 & 3 \\
\hline Limited supply & 106 & 1 & 136 & 3 & 166 & 1 & 170 & 2 \\
\hline Too many traders & 60 & 4 & 41 & 7 & 18 & 5 & 43 & 8 \\
\hline Lack of finance & 95 & 2 & 204 & 1 & 90 & 3 & 110 & 4 \\
\hline Inadequate capital & 79 & 3 & 200 & 2 & 143 & 2 & 184 & 1 \\
\hline Not enough customers & 14 & 6 & 24 & 8 & 6 & 8 & 72 & 6 \\
\hline Risk of quality deterioration & 19 & 5 & 99 & 5 & 69 & 4 & 74 & 5 \\
\hline Risk of price changes & 12 & 7 & 130 & 4 & 14 & 6 & 66 & 7 \\
\hline
\end{tabular}

Source: Author's computations based on data from survey of November $2000^{2}$.

2 Interviewees (traders) were asked to score the factors affecting volumes of sorghum traded. The most important factor is scored 7, while the least important is scored 1 . The table presents collated ranking results. 
TABLE 2

Market Integration Results Using Ravallion Model

\begin{tabular}{|c|c|c|c|c|c|c|c|c|c|c|}
\hline Market (1) & Market (2) & C & $P_{1 t-1}$ & $P_{I t-2}$ & $P_{2 t}$ & $P_{2 t-1}$ & $P_{2 t-2}$ & DUM & $R^{2}$ & $D W$ \\
\hline Bawku & Techiman & $\begin{array}{c}0.0540 \\
(0.4789)\end{array}$ & $\begin{array}{c}1.08213 \\
(11.7217)^{* * *}\end{array}$ & $\begin{array}{l}-0.2219 \\
(-2.4019) * *\end{array}$ & $\begin{array}{l}0.1906 \\
(2.7690) * * *\end{array}$ & $\begin{array}{l}-0.057986 \\
(-0.8634)\end{array}$ & 0.0467 & $\begin{array}{l}0.9873 \\
(2.6880) * * *\end{array}$ & 0.9873 & 2.1066 \\
\hline Bolga & Techiman & & $\begin{array}{c}0.17209 \\
(0.0910)^{*}\end{array}$ & & $\begin{array}{l}0.7359 \\
(0.3341) * *\end{array}$ & $\begin{array}{c}0.0845 \\
(0.3547)\end{array}$ & & $\begin{array}{c}0.8280 \\
(0.0690)\end{array}$ & 0.0821 & 2.076833 \\
\hline Zebilla & Techiman & $\begin{array}{c}0.1871 \\
(0.1474)\end{array}$ & $\begin{array}{l}0.9445 \\
(0.0982)^{* * *}\end{array}$ & $\begin{array}{l}-0.2097 \\
(0.1017)^{* *}\end{array}$ & $\begin{array}{l}0.5055 \\
(0.1559)^{* * *}\end{array}$ & $\begin{array}{l}-0.2639 \\
(0.1225) * *\end{array}$ & & $\begin{array}{l}0.0999 \\
(0.0240)^{* * *}\end{array}$ & 0.9759 & 2.01832 \\
\hline Bimbilla & Techiman & $\begin{array}{l}-0.0686 \\
(0.2430)\end{array}$ & $\begin{array}{l}0.334015 \\
(0.0943)^{* * *}\end{array}$ & & $\begin{array}{l}1.0587 \\
(0.2184)^{* * *}\end{array}$ & $\begin{array}{l}-0.3992 \\
(0.1946)^{*}\end{array}$ & & $\begin{array}{l}-0.0481 \\
(0.0373)\end{array}$ & 0.9446 & 1.9216 \\
\hline Gushiegu & Techiman & $\begin{array}{l}-0.3907 \\
(0.4185)\end{array}$ & & $\begin{array}{l}0.4009 \\
(0.0797) * * *\end{array}$ & $\begin{array}{l}1.0915 \\
(0.3449) * *\end{array}$ & $\begin{array}{l}-0.4592 \\
(0.3544)\end{array}$ & & $\begin{array}{l}-0.1105 \\
(0.0647)\end{array}$ & 0.8652 & 2.1127 \\
\hline Tamale & Techiman & $\begin{array}{c}0.1081 \\
(0.1217)\end{array}$ & $\begin{array}{l}0.5237 \\
(0.0811)^{* * *}\end{array}$ & & $\begin{array}{l}0.62033 \\
(0.0672)^{* * *}\end{array}$ & $\begin{array}{l}-0.1387 \\
(0.0955)\end{array}$ & & $\begin{array}{l}-0.0226 \\
(0.0180)\end{array}$ & 0.9858 & \\
\hline Bawku & Accra & $(0.1301)$ & $\begin{array}{l}0.9770 \\
(0.1082) * * *\end{array}$ & $\begin{array}{l}-0.2751 \\
(0.09351) * *\end{array}$ & $\begin{array}{l}0.2944 \\
(0.0874) * * *\end{array}$ & & & $\begin{array}{c}0.0213 \\
(0.0173)\end{array}$ & 0.9352 & 2.1157 \\
\hline Bolga & Accra & $\begin{array}{l}-0.53182 \\
(0.4739)\end{array}$ & $\begin{array}{c}0.0747 \\
(0.0973)\end{array}$ & & $\begin{array}{l}1.5441 \\
(0.6361)^{*}\end{array}$ & $\begin{array}{l}-0.5978 \\
(0.6361)\end{array}$ & & $\begin{array}{c}0.0332 \\
(0.0752)\end{array}$ & 0.9804 & 1.9261 \\
\hline Zebilla & Accra & $\begin{array}{c}0.0169 \\
(0.2438)\end{array}$ & $\begin{array}{l}0.7142 \\
(0.0965) * * *\end{array}$ & & $\begin{array}{l}1.8007 \\
(0.4404) * * *\end{array}$ & $\begin{array}{l}-1.5319 \\
(0.4046) * * *\end{array}$ & & $\begin{array}{l}0.1452 \\
(0.0401)^{* * *}\end{array}$ & 0.8754 & 2.0284 \\
\hline Bimbilla & Accra & $\begin{array}{l}-0.2114 \\
(0.3820)\end{array}$ & $\begin{array}{c}0.3522 \\
(0.2806)\end{array}$ & & $\begin{array}{l}2.6877 \\
(0.6659) * * *\end{array}$ & $\begin{array}{l}-2.04982 \\
(0.4853)^{* * *}\end{array}$ & & $\begin{array}{l}-0.0306 \\
(0.0579)\end{array}$ & 0.9861 & 2.1477 \\
\hline Gushiegu & Accra & $\begin{array}{l}-0.3318 \\
(0.4781)\end{array}$ & $\begin{array}{c}0.16374 \\
(0.0916)^{*}\end{array}$ & & $\begin{array}{l}0.7622 \\
(0.3342) * *\end{array}$ & $\begin{array}{c}0.07801 \\
(0.3328)\end{array}$ & & $\begin{array}{l}-0.1875 \\
(0.0727)^{* *}\end{array}$ & 0.9502 & 2.0041 \\
\hline Tamale & Accra & $\begin{array}{c}-.0638 \\
(-0.4326)\end{array}$ & $\begin{array}{c}0.672713 \\
(4.003)^{* * *}\end{array}$ & $\begin{array}{l}-0.1425 \\
(-1.5412)\end{array}$ & $\begin{array}{l}0.418461 \\
(4.0031)^{* * *}\end{array}$ & $\begin{array}{l}-0.2223 \\
(2.6035)^{*}\end{array}$ & 0.265787 & $\begin{array}{l}-0.088317 \\
(-3.8202)^{*} * *\end{array}$ & 0.8718 & 2.4070 \\
\hline Techiman & Accra & $\begin{array}{c}0.2326 \\
(0.1542)\end{array}$ & $\begin{array}{l}0.6478 \\
(0.0807) * * *\end{array}$ & $\begin{array}{l}0.4153 \\
(0.1189) * * *\end{array}$ & $\begin{array}{l}-0.3019 \\
(0.1462) * *\end{array}$ & $\begin{array}{l}0.2119 \\
(0.1053)^{* *}\end{array}$ & & $\begin{array}{l}-0.0924 \\
(0.0240) * * *\end{array}$ & 0.8203 & 1.9976 \\
\hline Bawku & Tamale & $\begin{array}{l}-0.2250 \\
(0.2818)\end{array}$ & $\begin{array}{c}0.1977 \\
(0.2935)\end{array}$ & & $\begin{array}{l}2.03354 \\
(0.6749)^{* * *}\end{array}$ & $\begin{array}{l}-1.2120 \\
(0.4112)^{* * *}\end{array}$ & & $\begin{array}{l}0.1794 \\
(0.0606)^{* * *}\end{array}$ & 0.9439 & 1.9226 \\
\hline Bolga & Tamale & $\begin{array}{c}0.0663 \\
(0.4364)\end{array}$ & $\begin{array}{c}0.03452 \\
(0.1024)\end{array}$ & & $\begin{array}{l}1.0304 \\
(0.3907) * * *\end{array}$ & $\begin{array}{l}-0.0679 \\
(0.3532)\end{array}$ & & $\begin{array}{c}0.13185 \\
(0.0720)\end{array}$ & 0.8265 & 2.0365 \\
\hline Zebilla & Tamale & $\begin{array}{c}0.3792 \\
(0.2155)^{*}\end{array}$ & $\begin{array}{c}0.8000 \\
(0.1482)\end{array}$ & $(0.1721)^{*}$ & $\begin{array}{l}-0.4396 \\
(0.2940) * * *\end{array}$ & $\begin{array}{l}1.4738 \\
(0.2576)^{* * * *}\end{array}$ & $\begin{array}{l}-0.9564 \\
*(0.1331)\end{array}$ & $\begin{array}{l}0.0816 \\
(0.0358) * * *\end{array}$ & 0.1394 & 1.8563 \\
\hline Bimbilla & Tamale & $\begin{array}{c}0.2449 \\
(0.2284)\end{array}$ & $\begin{array}{l}0.3289 \\
(0.0942)^{* * *}\end{array}$ & & $\begin{array}{l}0.9846 \\
(0.2148)^{* * * *}\end{array}$ & $\begin{array}{l}-0.34066 \\
(0.1950)^{*}\end{array}$ & & $\begin{array}{l}-0.0540 \\
(0.0360)\end{array}$ & 0.9308 & 1.8815 \\
\hline Gushiegu & Tamale & $\begin{array}{c}0.01498 \\
(0.3723)\end{array}$ & & $\begin{array}{l}0.4968 \\
(0.0884)^{* * *}\end{array}$ & $\begin{array}{l}1.2970 \\
(0.33537) * * *\end{array}$ & $\begin{array}{l}-0.7920 \\
(0.3806)\end{array}$ & & $\begin{array}{l}-0.1175 \\
(0.0591)\end{array}$ & 0.9888 & 1.8584 \\
\hline Zebilla & Bawku & $\begin{array}{l}0.3286 \\
(0.1272)^{*}\end{array}$ & $\begin{array}{l}0.5384 \\
(0.0924) * * *\end{array}$ & & $\begin{array}{l}1.2285 \\
(0.3674) * * *\end{array}$ & $\begin{array}{l}-0.8009 \\
(0.3294)^{*}\end{array}$ & & $\begin{array}{c}0.0203 \\
(0.0220)\end{array}$ & 0.8181 & 2.2172 \\
\hline
\end{tabular}

Standard error values are in parenthesis; $* * *$ indicates statistical significance at $99 \%$; ** indicates statistical significance at $95 \%$; and $* 90 \%$ 
TABLE 3

Results of Augmented Dickey-Fuler (ADF) Unit Root Test on Sorghum Price Series

\begin{tabular}{lccc}
\hline Market & $\begin{array}{c}\text { Levels } \\
t \text {-ADF }\end{array}$ & $\begin{array}{c}\text { First difference } \\
t \text {-ADF }\end{array}$ & No. of lags \\
\hline Techiman & -2.600316 & $-8.305 * *$ & 1 \\
Tamale & -2.988568 & $-8.234 * *$ & 1 \\
Gushiegu & -3.542668 & $-9.527 * *$ & 1 \\
Bolga & -3.945662 & $-11.886 * *$ & 1 \\
Bimbilla & -4.082056 & $-8.855 * *$ & 1 \\
Bawku & -2.304957 & $-6.747 * *$ & 1 \\
Accra & -2.234496 & $-9.107 * *$ & 1 \\
Zebilla & -2.791269 & $-7.621 * *$ & 1 \\
\hline
\end{tabular}

**Denotes $99 \%$ significance level with critical value of -3.487 that $\ddot{a}<0$.

The Augmented DickeyFuler (ADF) test results on the residuals (Equation 8) indicated rejection of the null hypothesis that $\hat{a}=0$ because the ADF test statistics for the market pairs were significant at 99 per cent using the Mackinnon critical values. It could, therefore, be concluded that all the market pairs that passed the Ravallion test were cointegrated. Thus, sorghum market prices were constant was also observed by Dittoh (1999). This could be explained by the effect of other shift variables such as expectations and behaviour of traders.

The R-squared values (which ranged between 82 and $98 \%$ ) indicated that high proportion of the variations in the dependent variables could be explained by the relevant independent variables. Results from the parameter restrictions using the Wald test indicated that sorghum prices in 95 per cent of the market pairs studied were integrated. However, prices were not immediately transmitted from the reference market to the local market, suggesting the absence of short-run integration within 1-month period. In other words, the null hypothesis that $\hat{\mathrm{a}}_{\mathrm{i} 0}=1$ and $\mathrm{a}_{\mathrm{ij}}=\hat{\mathrm{a}}_{\mathrm{ij}}=0$ was rejected at 1 per cent critical value.

\section{Cointegration approach}

Table 3 presents results of ADF test. The results showed that the price series were non-stationary in levels because the absolute values of ADF statistics were not greater than 3.487 at 1 per cent Mackinnon critical level. Thus, the null hypothesis of the unit root test $(\ddot{a}=0)$ could not be rejected. However, the series became stationary after first differencing, with the ADF statistics being greater than 3.487 at 1 per cent Mackinnon critical level, implying rejection of the null hypothesis in favour of alternative hypothesis over time, undisturbed by any local stochastic effects, and a unit increase in a reference market price was passed on fully to the local market in the long run. This suggested that arbitrage activities of traders, who transferred sorghum from local markets (low-priced area) to reference markets (high-priced area), resulted in raising prices in local markets while prices in reference markets were lowered until price differentials equalled transfer costs and all opportunities for earning 'abnormal' profits were eliminated.

Table 5 presents a summary of short-run integration test results, using the Error Correction model. Only the results of market pairs that showed good enough fit with absence of serial correlation among the vectors were presented. The results indicated that the coefficient of the Error Correction term $\left(e_{t-1}\right)$ for all the market pairs were significantly different from zero at 1 per cent critical level. For $\hat{a}_{\mathrm{i}}$, the coefficients for Gushiegu -Accra, Gushiegu - Tamale, and Tamale -Techiman were significantly different from zero at 1 per cent critical level. The estimated coefficient for BolgaTechiman was significant at 5 per cent critical level, while that for Bolga-Accra was significant at 10 per cent critical level. The coefficient ( $\hat{a}_{\mathrm{i}}$ ) for Bolga -Tamale was not significantly different from zero. However, the null hypothesis that $\left(\kappa_{\mathrm{i}}\right)=-1$ and $\hat{\mathrm{a}}_{\mathrm{i}}=$ 1 could not be rejected for Bolga-Techiman, 
TABLE 4

Cointegration Results Using Engle-Granger Procedure

\begin{tabular}{lcccc}
\hline Market pair & $t$-ADF & No. of lags & $R^{2}$ & $F$-statistic \\
\hline Bawku-Techiman & $-6.1983 * * *$ & 2 & 0.5220 & 40.4157 \\
Bolga-Techiman & $-6.4004 * * *$ & 2 & 0.5399 & 40.0168 \\
Zebilla-Techiman & $-6.5218 * * *$ & 3 & 0.5222 & 23.6095 \\
Bimbilla-Techiman & $-6.2403 * * *$ & 2 & 0.4980 & 26.8635 \\
Gushiegu-Techiman & $-5.7155 * * *$ & 3 & 0.5485 & 26.2486 \\
Tamale-Techiman & $-4.6043 * * *$ & 4 & 0.4808 & 19.8179 \\
Bawku-Accra & $-6.3810 * * *$ & 3 & 0.5477 & 26.1614 \\
Bolga-Accra & $-5.0767 * * *$ & 3 & 0.5103 & 28.6578 \\
Zebilla-Accra & $-7.5383 * * *$ & 2 & 0.54044 & 32.6314 \\
Bimbilla-Accra & $-8.2578 * * *$ & 2 & 0.6112 & 60.7576 \\
Gushiegu-Accra & $-4.3877 * * *$ & 4 & 0.6592 & 41.7849 \\
Tamale-Accra & $-6.2555 * * *$ & 4 & 0.5396 & 28.9492 \\
Techiman-Accra & $-4.4080 * * *$ & 4 & 0.4930 & 20.8171 \\
Bawku-Tamale & $-5.0983 * * *$ & 3 & 0.4841 & 20.2708 \\
Bolga-Tamale & $-5.3720 * * *$ & 2 & 0.5152 & 39.6820 \\
Zebilla-Tamale & $-6.0558 * * *$ & 3 & 0.5200 & 23.1922 \\
Bimbilla-Tamale & $-6.7371 * * *$ & 2 & 0.4903 & 35.9140 \\
Gushiegu-Tamale & $-7.2099 * * *$ & 4 & 0.5277 & 23.9127 \\
Zebilla-Bawku & $-5.3559 * * *$ & 4 & 0.4786 & 19.8315 \\
\hline
\end{tabular}

***Denotes significance at $1 \%$ Mackinnon critical value of -4.0407

**Denotes significance at 5\% Mackinnon critical value of -4.0407

TABLE 5
Gushiegu-Accra, BolgaAccra, Bolga-Tamale and Gushiegu-Tamale as indicated in the Wald test results; suggesting that only 25 per cent of the market pairs studied was integrated in the short run. The values of $\left(\hat{a}_{\mathrm{i}}\right)$ also indicated that, averagely, about 70 per cent of the price changes in the reference markets were transmitted to the local markets after 1 month.

The lack of short-run integration in most markets could be attributed to inadequate information flow in the marketing system. Most traders at the local

Summary of Short-run Integration Test Results Using the Error Correction Model

\begin{tabular}{|c|c|c|c|c|c|c|}
\hline \multirow[b]{2}{*}{ Market pair } & \multirow[b]{2}{*}{$\begin{array}{c}\text { Coefficient } \\
k_{i}\end{array}$} & \multicolumn{2}{|c|}{$\begin{array}{l}\text { Walt test results } \\
\qquad k_{i}-1\end{array}$} & \multirow[b]{2}{*}{$\begin{array}{c}\text { Coefficient } \\
\beta_{i}\end{array}$} & \multicolumn{2}{|c|}{$\begin{array}{l}\text { Walt test results } \\
\qquad \beta_{i}=1\end{array}$} \\
\hline & & $\begin{array}{l}F \text {-stat } \\
(\text { prob })\end{array}$ & $\begin{array}{c}\text { Chi-square } \\
(\text { prob })\end{array}$ & & $\begin{array}{c}F \text {-stat } \\
(\text { prob })\end{array}$ & $\begin{array}{c}\text { Chi-square } \\
(\text { prob })\end{array}$ \\
\hline Bolga-Techiman & $\begin{array}{l}-0.8820 \\
(-9.0458) * * *\end{array}$ & $\begin{array}{c}3.2445 \\
(0.0744)\end{array}$ & $\begin{array}{c}3.2445 \\
(0.0716)\end{array}$ & $\begin{array}{l}0.5643 \\
(2.0478) * *\end{array}$ & $\begin{array}{c}2.4999 \\
(0.1167)\end{array}$ & $\begin{array}{c}2.4999 \\
(0.1138)\end{array}$ \\
\hline Gushiegu-Accra & $\begin{array}{l}-0.8461 \\
(-8.9308) * * *\end{array}$ & $\begin{array}{c}2.6379 \\
(0.1071)\end{array}$ & $\begin{array}{c}2.6379 \\
(0.1043)\end{array}$ & $\begin{array}{l}0.8976 \\
(2.9691)^{* * * *}\end{array}$ & $\begin{array}{c}0.1145 \\
(0.7356)\end{array}$ & $\begin{array}{l}0.1145 \\
(0.735)\end{array}$ \\
\hline Bolga-Accra & $\begin{array}{l}-0.9413 \\
(-9.8195) * * *\end{array}$ & $\begin{array}{c}0.3749 \\
(0.5415)\end{array}$ & $\begin{array}{c}0.3749 \\
(0.5403)\end{array}$ & $\begin{array}{l}0.5496 \\
(1.7772)^{*}\end{array}$ & $\begin{array}{c}2.1200 \\
(0.1482)\end{array}$ & $\begin{array}{c}2.1200 \\
(0.1453)\end{array}$ \\
\hline Bolga-Tamale & $\begin{array}{l}-0.9178 \\
(-9.3927) * * *\end{array}$ & $\begin{array}{c}0.7070 \\
(0.4022)\end{array}$ & $\begin{array}{c}0.7070 \\
(0.4004)\end{array}$ & $\begin{array}{c}0.4673 \\
(1.6381)\end{array}$ & $\begin{array}{c}3.4868 \\
(0.0645)\end{array}$ & $\begin{array}{c}3.4868 \\
(0.0618)\end{array}$ \\
\hline Gushiegu-Tamale & $\begin{array}{c}-0.9755 \\
(-10.222) * * *\end{array}$ & $\begin{array}{c}0.0655 \\
(0.7983)\end{array}$ & $\begin{array}{c}0.0655 \\
(0.7978)\end{array}$ & $\begin{array}{l}1.04677 \\
(4.6757) * * *\end{array}$ & $\begin{array}{l}0.04365 \\
(0.8348)\end{array}$ & $\begin{array}{l}0.04365 \\
(0.8344)\end{array}$ \\
\hline Tamale-Techiman & $\begin{array}{l}-0.4162 \\
(-4.1763) * * *\end{array}$ & $\begin{array}{l}34.3030 \\
(0.0000)\end{array}$ & $\begin{array}{l}34.3030 \\
(0.0000)\end{array}$ & $\begin{array}{l}0.6485 \\
(9.7777)^{* * * *}\end{array}$ & $\begin{array}{r}28.0759 \\
(0.0000\end{array}$ & $\begin{array}{l}28.0759 \\
(0.0000)\end{array}$ \\
\hline
\end{tabular}

$* * *$ Denotes significance at $1 \%$ critical level; $* *$ Denotes significance at $51 \%$ critical level; *Denotes significance at $10 \%$ critical level 
markets had very little information on reference market prices. However, 70 per cent of traders in the reference markets were well informed about sorghum prices through various sources, including the radio, agents and other traders.

Lack of well-integrated communication network in the marketing system created the tendency for some traders to keep specific information on prices and availability of sorghum, which could lead to market inefficiencies. For an environment in which information is incomplete or asymmetric, producers, traders, and consumers have to manage risky situations, which could hamper the functioning of markets. Another factor that could be considered is the effects of transportation system and infrastructure on market integration, which have not been econometrically examined in this study.

Table 6 depicts the number of lags used in the Error Correction model. This is determined by using Hendry's general-to-specific modeling approach.

Some main causes of asymmetric price transmission are non-competitive markets and adjustment costs, political intervention, and inventory management (Levy et al., 1997; Dutta et al., 1999; Meyer \& Cramon-Taubadel, 2004). As observed in the organisation of sorghum market, there was no cooperative behaviour among traders and no political intervention in pricing. It was, therefore, conjectured that no asymmetry in price transmission existed. However, others have suggested that market integration in Market 1 with price $\mathrm{p}_{1}$, and Market 2 with price $\mathrm{p}_{2}$

$$
\text { TABLE } 6
$$

Number of Lags Used in the Error Correction Model

\begin{tabular}{ll}
\hline Market pair & No. of lags \\
\hline Bolga-Techiman & 3 \\
Gushiegu-Accra & 2 \\
Bolga-Accra & 3 \\
Bolga-Tamale & 3 \\
Gushiegu-Tamale & 3 \\
\hline
\end{tabular}

will imply that $\mathrm{p}_{1}$ causes $\mathrm{p}_{2}$ and vice versa (Rapsomaniskis, Hallam \& Conforti, 2004).

\section{Conclusion}

Generally, sorghum cultivation is unimodal with harvesting in October-December, depending on the rainfall pattern in any particular year. However, the study showed that stocks are held for relatively stable supply throughout the year, especially at the market level. Farm-level storage was minimal because of urgent cash needs by farmers. Sorghum prices usually peaked in November-December, while low prices were registered in January-February after the harvesting period. Factors affecting volumes of sorghum traded were variable and location-specific. These factors included transportation difficulties, limited supply, inadequate capital, lack of finance, number of sellers and buyers, risk of price changes, and quality deterioration.

On sorghum market integration analysis, the study established lack of short-run integration in 75 per cent of the sorghum market pairs studied. The price adjustment mechanism between local and reference markets was relatively slow, but markets were integrated in the long run. This could be attributed to lack of adequate market information system in the local markets and, possibly, transportation difficulty. The scope of this study could not afford a detailed study in this direction. However, it can be concluded that the efficiency of arbitrage activities in the sorghum market needs to be improved by strengthening the market information system. Future studies may further investigate the existence or non-existence of asymmetry. Granger causality of the price in one market by the price in another (and vice versa) could also be tested in future studies.

\section{REFERENCES}

Alderman, H. (1990) Nutritional status in Ghana and its determinants: Social dimensions of adjustment in sub-Saharan Africa. Working Paper No. 3. Washington, DC: World Bank.

Alexander, C. \& Wyeth, J. (1994) Cointegration and 
market integration: An application to the Indonesian rice market. J. Dev. Stud. 30, 303-328.

Barret, C. B. (2001) Measuring integration and efficiency in international agricultural markets. Rev. agric. Econ. 23(1), 19-32.

Barret C. B \& Li, J. R. (2002) Distinguishing between equilibrium and integration in spatial price analysis. Am. J. agric. Econ. 84(2), 292.

Charemza, W. W. \& Deadman, D. F. (1992) New directions in econometric practice.

Dittoh, S. (1999) Market integration: The case of dry season vegetables in Nigeria. University of Ibadan, Nigeria (Typescript).

Dercon, S. (1995)On market integration and liberalization: Method and application to Ethiopia. J. Dev. Stud. 32 (2), 112-143.

Dutta, S., Bergen, M., Levy, D. \& Venable, R. (1999) Menu cost, postal prices, and multiproduct retailers. Journal of Money, Credit, and Banking 31(4 ), 683703.

Engle, R. F. C. \& Granger, C. W. J. (1987) Cointegration and error correction: Representation, estimation, and testing. Econometrica 55(2), 251276.

Goletti, F. \& Babu, S. (1994) Market liberalization and market integration of maize markets in Malawi. Agric. Econ. 11, 311-324.

Goodwin, B. \& Schroeder, T. C. (1991) Cointegration tests and spatial rice linkages in regional cattle market. Am. J. agric. Econ. 73, 452-464.

Hendry, D. F., Pagan, A. R. \& Sargan, J. D. (1984) Dynamic specification: Handbook of econometrics, Vol. 2 (ed. Z. Griliches and M. D. Intriligator). Amsterdam: North-Holland Publishing Co.

Heyten, P. (1986) Testing market integration. Fd Res. Inst. 20(1), 25-41.

Jayne,T. S., Takavarasha, T. \& Johan van Zyl (1994) Interaction between food market reform and regional trade in Zimbabwe and South Africa: Implications for food security. MSU International Development Working Paper No. 48. Department of Agricultural Economics.
Levy, D., Bergen, M., Dutta, S. \& Venable, R. (1997) The magnitude of menu costs: Direct evidence from large US supermarket chains. $Q$. Jl Econ. 112(3), 791-825.

Lutz, C. \& van Tilburg, A. (1997) Framework to assess the performance of food commodity marketing systems in developing countries with application to the maize market in Benin. In Sustainable food security in West Africa (ed. W. K. Asenso-Okyere, G. Benneh and W. Tims). Kluwer Academy Publishers. London, UK.

Maheshwari, A. (1993) Market fragmentation and market sharing in wholesale trade centers in Karnataka. Indian J. agric. Econ. 48(4), 659-666.

Meyer, J. \& Cramon-Taubadel, S. (2004) Asymmetric price transmission. Surv. J. agric. Econ. 55(3), 581-611.

Ministry of Food and Agriculture (MOFA) (1990) Medium Term Agricultural Development Plan (MTADP): An Agenda for Sustained Agricultural Development (1991-2000). Vol. 1. Accra, Ghana.

Morgan, R. M. \& Hunt, S. D. (1994) The commitmenttrust theory of relationship marketing. J. Mktg, pp. 20-38. No. 10 Cornell Food and Nutrition Policy Program.

Rapsomaniskis, G., Hallam, D. \& Conforti, P. (2004) Market integration and price transmission in selected food and cash crop markets of developing countries: Review and applications. Economic and Social Department, FAO.

Takayama,T. \& Judge, G. (1971) Spatial and temporal price and allocation models. Amsterdam, Holland: North Holland.

Timmer, P. (1981) Is there curvature in the Slutsky matrix? Rev. Econ. Statists 63(3), 395-402.

Sahn, D. (1989) Seasonal variability in Third World agriculture: The consequences for food security. Baltimore, MD: Johns Hopkins University Press.

Smith, L. E. D., Khushk, A. M. \& Stockbridge, M. (1999) Case studies of corruption in agricultural markets in Sindh Province, Pakistan, and implications for market liberalization. J. int. Fd Agribusin. Mktg 11(1), 19-41. 